Doi: $10.4274 /$ vhd. 02411

Viral Hepatitis Journal 2014; 20(2): 43-48

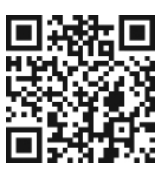

\title{
Viral hepatitis in Denmark
}

\author{
Danimarka'da Viral Hepatitler
}

\author{
Işık SOMUNCU JOHANSEN1, Nina WEIS2, Peer BREHM CHRISTENSEN1 \\ 1 Odense University Hospital University of Southern Denmark, Department of Infectious Diseases, Odense, Denmark \\ ${ }^{2}$ Copenhagen University Hospital, Department of Infectious Diseases, Copenhagen, Denmark
}

\begin{abstract}
To provide an overview of the epidemiology and public health strategies concerning viral hepatitis in Denmark. Studies and guidelines in viral hepatitis in Denmark and national surveillance data were reviewed. The incidence of acute hepatitis A has declined since 1980 and was 0.2/105 in 2011. The majority of cases are imported by children of foreign origin. The incidence of acute hepatitis $B$ has also been declining; the prevalence of chronic hepatitis $B$ is estimated to be $0.24 \%$ of the adult population and genotype $D$ is the most prevalent. The majority of patients with chronic hepatitis $B$ are immigrants from high incidence regions and co-infection with hepatitis $D$ is rare. The prevalence of hepatitis $\mathrm{C}$ is $0.38 \%$ of the adult population and the majority has been infected through 4 drug use. Genotype 1 is the most prevalent genotype. Hepatitis $\mathrm{E}$ is a rare and imported condition but a high prevalence of anti-HEV among farmers indicates the infection is an asymptomatic zoonotic infection in Denmark. There are national treatment guidelines for hepatitis $B$ and $C$ and the treatment is provided free of charge to all Danish residents. Vaccination against hepatitis $A$ is recommended to persons travelling to high incidence countries and persons with chronic hepatitis C. Vaccination against hepatitis B is recommended and free of charge to all newborns of HBsAg positive mothers and persons specifically assessed to be at an increased risk. Denmark is a low incidence country for viral hepatitis, but continuous attention is required within risk groups. (Viral Hepatitis Journal 2014; 20(2): 43-48)
\end{abstract}

Key words: Hepatitis A, hepatitis B, hepatitis C, hepatitis E, Denmark

\section{ÖZET}

Bu çalısmada Danimarka viral hepatit epidemiyolojisi ve koruyucu stratejilerine bir bakış sağlamak amaçlanmıştır. Danimarka'daki viral hepatit üzerine olan bilimsel çalışmalar ve uygulamalar ve ulusal sürveyans verileri değerlendirildi.. Akut hepatit A insidansı 1980'den beri düşmekte ve 2011 yllında insidans 0,2/100,000 ve olguların çoğunluğunun yabancı kökenli çocuklar tarafından endemik ülkelerden ithal edilmektedir. Akut hepatit B görülme sıklığında ciddi azalma görülürken; tahmini kronik hepatit B sıklı̆̆ının erişkin nüfusun \% 0,24'ü olduğu belirlendi. Genotip D en yaygın olanıdır. Kronik hepatit B olgularının çoğunu yüksek insidans bölgelerden gelen göçmenler oluşturur. Hepatit $D$ ile ko-enfeksiyon ise nadir görülüyor. Hepatit C prevelansi \% 0,38 ve olguların çoğunlugu 4 uyuşturucu kullanımı ile enfekte olmuştur. Genotip 1 en yaygın genotipdir. Hepatit $\mathrm{E}$ çok nadir görülen ve olguların çoğu endemikülkelerde enfekte olurken, çiftçilerin arasında tespit edilen yüksek antiHEV prevalansı, hepatit E'nin Danimarka'da bir asemptomatik zoonotik enfeksiyon olduğunu gösterir. Hepatit B ve C için ulusal tedavi kılavuzları geliştirilmiş ve tedavi Danimarka da yaşayanlara ücretsiz sağlanmaktadır. Hepatit $A$ asisi endemik ülkelere seyehat edenlere ve kronik hepatit $C$ enfeksiyonu olanlara öneriliyor. Hepatit B asisi HBsAg pozitif anneden doğan bebeklere ve hepatit B bulaşma riski yüksek olan kişilere önerilir ve ücretsiz olarak aşılama yapılır. Danimarka'da viral hepatit insidansi düşük ve risk gruplarına odaklı devamlı bir preventif strateji gereklidir. (Viral Hepatit Dergisi 2014; 20(2): 43-48)

Anahtar Kelimeler: Hepatit A, hepatit B, hepatit C, hepatit E, Danimarka

\section{Denmark}

Denmark is a Scandinavian country with 5.6 million inhabitants (Figure 1). In total, 4.996 .980 persons of the population are of Danish descent. Immigrants and their descendants constitute 567.932 persons. The life expectancy for women is 81.6 years and for men, 77.3 years.

The basic principle of the Danish welfare system is that all citizens, free of charge, have equal rights and access to social security and health care. The Danish welfare model is subsidized by the state, and as a result, Denmark has one of the highest taxation levels in the world.

\section{Epidemiology of Viral Hepatitis}

\section{Hepatitis A}

In Denmark, anti-HAV IgM positive hepatitis A virus (HAV) infection is a mandatory notifiable disease. HAV infection is not regarded as endemic in Denmark and susceptibility in the Danish population is high. The incidence declined during the last decades from 5.5 per 100.000 in 1980 to 0.2 per 100.000 in 2011, attributable to improved sanitary and living conditions (Figure 2) (1). The majority of HAV infections in Denmark are imported by children of foreign origin, returning from visits to relatives in 
endemic countries $(1,2)$. Subsequent secondary spread in childcare institutions is a common cause of small outbreaks. Other major outbreaks of hepatitis A have been seen among men who have sex with men (MSM). In Copenhagen, outbreaks in MSM occurred in 1977 and in 1991 with 21 and 17 reported persons with hepatitis A, respectively $(3,4)$. The latest and largest outbreak of hepatitis A in MSM was in 2004 and involved a total of 240 persons of whom 186 were male (4). Minor outbreaks among intravenous (4) drug users have also been seen $(5,6)$.

In the ten-year period from 2000 to 2009 , a total of 747 persons were notified with HAV infection in Denmark. The majority of these persons were observed among persons of Danish origin in 2004 (200/447 persons) due to a major outbreak among MSM as described above. In total, 300 (40\%) of 747 persons have been notified with hepatitis A occurred in persons of foreign origin. Twentyfive percent of the persons were of Danish origin and $75 \%$ of foreign origin was infected abroad. Persons aged $<20$ years comprised $17 \%$ of persons of Danish origin, and $81 \%$ of persons of foreign origin (7).

Since the end of 2006, virus typing in patients diagnosed with hepatitis A has been performed routinely at Staten Serum Institut in Denmark. This provides important epidemiological information on the spread of hepatitis A from various countries. Furthermore, virus typing is an important tool to investigate and monitor outbreaks. Recently, the European surveillance alerted that since November 2012, there has been an increase in reported cases of hepatitis A in tourists returning from Egypt in several European countries, including Denmark (8). The majority of these persons shared an identical hepatitis A viral RNA sequence.

In February 2013, an increase in the number of persons notified with hepatitis A was observed in Denmark. These cases did not belong to the traditional hepatitis $A$ risk groups and were geographically spread across the whole country. A case-control study disclosed that frozen strawberries were the cause of the outbreak (9).

\section{Hepatitis B}

The prevalence of hepatitis $B$ in Denmark is unknown but presumed to be low. Notification of chronic hepatitis B virus (HBV) infection to the national register of notifiable diseases has been mandatory since May 2000, but reporting rates are low (10). All notified cases of HBV infection are shown in (Figure 2).

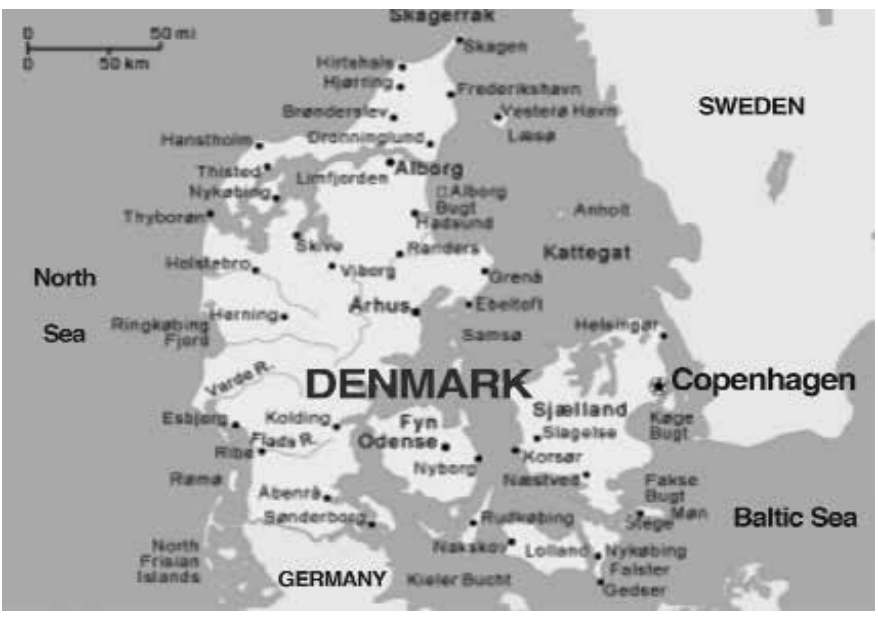

Figure 1. Denmark.

\section{Acute Hepatitis B}

The features of the acute hepatitis B infection have changed during the last decades in Denmark. The infection was diagnosed mainly among drug addicts in the 1970s (6). In the early 1980s, the disease was mainly presented as a sexually transmitted infection, particularly among MSM (3). In the 1990s 4 drug addicts in Denmark were again the affected group (11), although sexual transmission continued to constitute a significant proportion. The reported incidence of acute hepatitis B in Denmark has been declining during the last two decades to $0.4 / 100.000 /$ per year; in contrast, the incidence of diagnosed chronic hepatitis $\mathrm{B}$ has increased to 5.2/100.000/per year (Figure 3) (12). In 2010, 27 persons were notified with acute hepatitis $B$ of whom 21 were males. The median age was 40 years (range 20-81 years). Among the notified persons, $22(81 \%)$ were Danish-born and five $(19 \%)$ were immigrants. A total of $18(67 \%)$ were infected in Denmark; among these, 14 were Danish-born. Four persons (15\%) were infected abroad, all Danish-born. Twelve of the 27 persons were infected by heterosexual contact, five by homosexual contact, and for ten persons, the route of infection was unknown (13).

\section{Chronic Hepatitis B}

The National Board of Health estimated the prevalence of chronic hepatitis B in Denmark to be $0.28 \%$ (15.000 patients) in 2002 (14). Since November 2005, all pregnant women have been screened for hepatitis $\mathrm{B}$ virus and based on the national screening data from 2005 to 2007, the prevalence of hepatitis B was estimated to be $0.2 \%-0.3 \%$ in 2007 (15). Recently, Christensen et al. re-estimated the prevalence of HBV infection by the capture-recapture method using four nationwide registers and including undiagnosed patients. They found that the current adult population alive with HBV infection included approximately 11.000 patients corresponding to a prevalence of $0.24 \%$ of the adult Danish population. Their results also showed that two thirds of the infected population had been diagnosed, but only $17 \%$ attended specialized clinical care (manuscript in preparation).

In 2010, a total of 136 persons with chronic HBV infection were notified, 79 (58\%) were females, including 29 (37\%) pregnant women. The median age was 33 years (range 1-65 years). Among the notified persons, $15(13 \%)$ were of Danish origin and 121 $(87 \%)$ of foreign origin. The immigrants were spread across 42

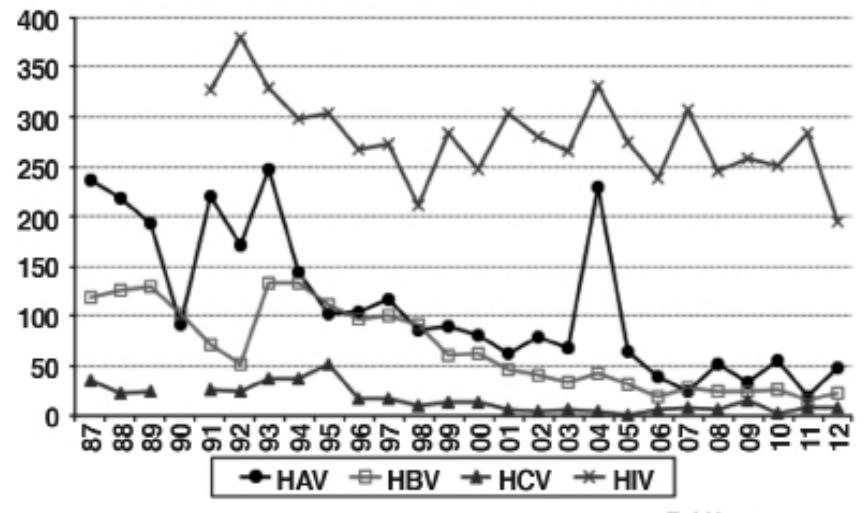

Epi-News 51;2012

Figure 2. Notified cases of HIV and viral hepatitis infection in Denmark from 1987 to 2012 
nationalities and 55 (46\%) were from Asia. The most frequent route of infection was mother-to-child transmission, all in the immigrant population (13). In 2012, 63.996 (99.8 \%) pregnant women were screened for hepatitis B and of those,118 HBsAg-positive ones were tested for the first time. Since 2007, the number of children infected with hepatitis B during labour in Denmark has decreased significantly due to the routine screening (16).

The prevalence of HBV genotypes in Denmark is $10.5 \%$ for $A, 17.3 \%$ for $B, 20.5 \%$ for $C, 45.7 \%$ for $D, 3.2 \%$ for $E, 0.6 \%$ for F $1.1 \%$ for $G$, and $1 \%$ with more than one genotype. Nearly $60 \%$ of the patients with genotype A are from Africa, $82 \%$ and $93 \%$ with genotypes B or C are from East Asia, 62\% with genotype D come from the Middle East, and $91 \%$ with genotype $\mathrm{E}$ come from Africa (17).

Co-infection with hepatitis $D$ virus is a minor problem in Denmark.

\section{Hepatitis C}

Hepatitis $C$ is not a common disease in Denmark but the exact prevalence is unknown. In the Scandinavian countries, the large majority of patients have been infected through 4 drug use. In Denmark, $74 \%$ of the reported persons were 4 drug users in 2011 (18). The prevalence of anti-hepatitis $\mathrm{C}$ virus (HCV) antibodies among 4 drug users has been reported to be between $62 \%$ and $97 \%$ (19-22). Patients with hemophilia, patients undergoing hemodialysis, multi-transfused patients and patients originating from high endemic areas also have an increased prevalence of HCV infection $(20,23)$. Seroprevalence surveys of the general population are the gold standard for determining the number of HCV-infected individuals within a country. This is time-consuming and costly to perform and have never been done in Denmark. Notification of acute HCV infection to the national register of notifiable diseases has been mandatory since 1991 and chronic HCV since May 2000. Recently, Christensen et al. studied the prevalence of $\mathrm{HCV}$ using four national registers of patients with a diagnosis of chronic hepatitis C: a laboratory register (DANVIR), the Hospital Discharge Register, The Danish Database for Hepatitis B and $\mathrm{C}$ (DANHEP), which is a clinical database of patients admitted to hospital in Denmark with chronic viral hepatitis, and The Register of Communicable Diseases. The total population diagnosed with hepatitis C was estimated by capture-recapture analysis. The

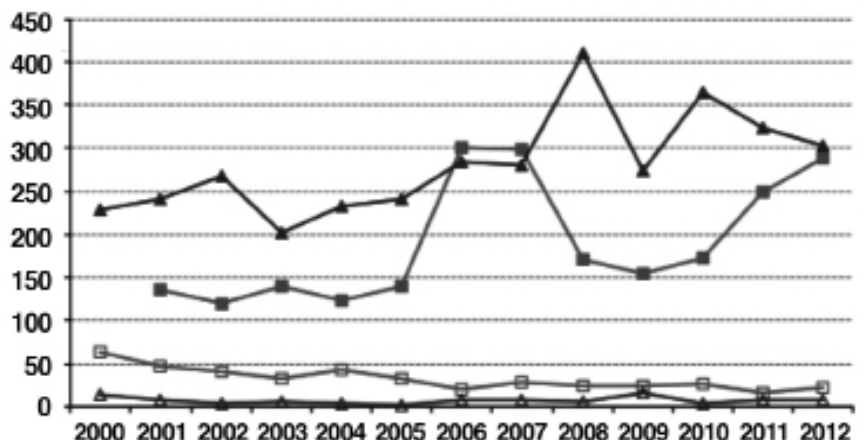
2000200120022003200420052006200720082009201020112012

-chronic HBV —acute HBV † acute HCV ‡ chronic HCV

Epi-News 51;2012

Figure 3. Notified cases of acute and chronic viral hepatitis in Denmark. population with undiagnosed hepatitis $C$ was derived from the national register of 4 drug users by comparing diagnosed and tested persons. A total of 6.935 patients diagnosed with chronic hepatitis $\mathrm{C}$ were identified in the four registers and the estimated population diagnosed with the disease was 9.166 persons $(95 \%$ C.I. interval 8.973-9.877). The prevalence was highest among persons $40-49$ years of age $(0.39 \%)$ and in males $(0.28 \%)$. In total, $40 \%$ of the diagnosed patients were living in the capital region, and only $33.5 \%$ had attended specialized healthcare. It was estimated that $46 \%$ of hepatitis $C$ patients had not been diagnosed and the total population with chronic hepatitis $\mathrm{C}$ in Denmark was 16.888 (95\% C.I. 16.474-18.287), corresponding to a prevalence of $0.38 \%$ (95\% Cl 0.37-0.42) of the adult population (24).

$\mathrm{HCV}$ infection has increasingly been reported as a sexually transmitted disease among MSM, especially with HIV co-infection during the last decade (25). Barfod et al. found that the incidence of HCV infection among Danish human immunodeficiency virus (HIV)-positive MSM was 0.4\% per year (26).

All donor blood have been screened for HCV since 1991 in Denmark and nosocomial mode of transmission has been notified in less than $10 \%$ of cases each year. These cases were either infected by blood products prior to 1991 or after admission to hospitals in high endemic countries (18). Notified cases of acute and chronic hepatitis C infection from 2000 to 2012 in Denmark are shown in (Figure 3).

The most common HCV genotypes are genotypes 1a (43\%), 3a (39\%), 1b (11\%), and 2b (6\%) in Denmark (27). However, genotype 4 has an increased prevalence of approximately $2 \%$ among patients with hepatitis $\mathrm{C}$ referred to hospital departments in Denmark (28).

In the most recent combined population-based case-control and cohort studies, it was shown that low socioeconomic status is associated with an increased risk of HCV infection and with poor prognosis in HCV-infected patients in Denmark (29). Omland et al. reported in a nationwide study that patients with chronic HCV infection are at higher risk of death than patients who cleared the infection. Chronic HCV infection greatly increased the risk of death from primary liver cancer in Denmark (30).

\section{Hepatitis E}

In Denmark, hepatitis $\mathrm{E}$ is considered a rare imported condition. From 2002 to 2007, one to eight persons with acute hepatitis E virus (HEV) infection were detected annually. During the first seven months of 2008, a total of 10 persons with acute hepatitis E were detected in Denmark. In six of these, a relevant travel history was found. Four of the persons were presumably infected in Denmark (31).

Persons with hepatitis $\mathrm{E}$ with no relevant travel history have recently been reported from several Western countries (32). Characterization of virus from these persons has shown a different serotype (serotype 3 ) than the imported cases, which are most frequently of serotype 1 . Until 2006, only persons with a relevant travel history to endemic areas were tested for hepatitis $E$ in Denmark. Following findings of hepatitis $E$ cases in European countries, the procedures were changed and now all samples sent for "acute hepatitis testing" are tested for HEV.

Furthermore, Christensen et al. found that the prevalence of anti-HEV was $50.4 \%$ among farmers and $32.9 \%$ among donors in 
1983 and 20.6\% among donors in 2003 in Denmark (33). These findings support the hypothesis that hepatitis $E$ virus infection in Denmark may be an asymptomatic zoonotic infection.

\section{National Treatment Guidelines for Viral Hepatitis}

The Danish National Board of Health recommends that all patients with chronic viral hepatitis should be followed with regular intervals at clinics specialized in either infectious diseases or gastroenterology/hepatology. The primary aim is to identify patients with significant liver disease to initiate treatment in order to prevent development of cirrhosis, hepatocellular carcinoma (HCC) and death. Medical care, including antiviral treatment, is provided free of charge to all Danish residents. The Danish Society of Infectious Diseases and Danish Society of Gastroenterology and Hepatology set up a committee in 2007 to produce national guidelines for treatment of viral hepatitis B and $\mathrm{C}$. The current guideline was published in 2012 (34) and summarizes as follows:

\section{Treatment for Hepatitis B}

The upper limit of normal (ULN) for alanine aminotransferase (ALT) has recently been increased to $70 \mathrm{IU} / \mathrm{L}$ for males and $50 \mathrm{IU} / \mathrm{L}$ for females in Scandinavia. However, large studies have shown that healthy persons and patients cured of viral hepatitis have an ULN of $30 \mathrm{IU} / \mathrm{L}$ for males and $19 \mathrm{IU} / \mathrm{L}$ for females $(35,36)$. As most treatment studies for hepatitis $B$ have been based on a ULN for ALT of approximately $50 \mathrm{IU} / \mathrm{L}$ for males and $35 \mathrm{IU} / \mathrm{L}$ for females, these limits are recommended in treatment decisions for hepatitis B patients in Denmark.

\section{Acute Hepatitis B}

In Denmark, only $10 \%$ of acute HBV cases are detected by anti$\mathrm{HBc}$ in the "window phase" where HBsAg has become negative and anti-HBs is not yet positive. Patients with an international normalized ratio (INR) above 1.7 are admitted to hospital, and in this population, the mortality rate is around $1 \%$. Patients with fulminant hepatitis (INR $>2.5$ or development of hepatic encephalopathy) are transferred to the liver transplant unit of Copenhagen University Hospital, Rigshospitalet, the only center for liver transplantation in Denmark.

\section{Chronic Hepatitis B}

It is recommended that all patients positive for HBsAg or HBVDNA are evaluated in a department specialized in viral hepatitis. Beside clinical history, liver function tests and HBV virology, patients are also tested for other liver diseases (other viral hepatitis, autoimmune disease, etc.). Liver biopsy is recommended for all patients with an ALT > ULN (50 IU/L for males, $35 \mathrm{IU} / \mathrm{L}$ for females) and/or serum HBV-DNA $>2.000 \mathrm{IU} / \mathrm{mL}$ in order to determine if the patients fulfill treatment indications. Non-invasive test (transient elastography) is increasingly used to rule out significant fibrosis, but for patients with a LSM $>7 \mathrm{kPa}$, a liver biopsy should be considered.

Danish treatment indications are identical for $\mathrm{HBeAg}$ positive and anti-HBe positive disease:

1) A liver biopsy shows activity $\geq A 2$ and/or fibrosis $\geq F 2$ according to the Danish modification of the METAVIR score

2) Either HBV-DNA $>2000 \mathrm{IU} / \mathrm{L}$ or ALT $>$ ULN.

Treatment should also be considered in all patients with cirrhosis, regardless of HBV-DNA level, in patients with a family history of $\mathrm{HCC}$ and, in the last trimester of pregnancy, in women with HBV-DNA $\geq 106 \mathrm{IU} / \mathrm{mL}$. In contrast, patients who only have elevated ALT and high HBV-DNA without histological changes are not recommended treatment.

The immediate goals of the treatment are to achieve undetectable HBV-DNA (<10-20 IU/mL), HBeAg seroconversion to anti-HBe, and ALT $<U L N$. This may lead to the long-term goals: normalization of liver histology and eventually, $\mathrm{HBsAg}$ seroconversion to anti-HBs.

Treatment can be of finite duration or continuous. Treatment with nucleoside analogs for $\mathrm{HBeAg}$ positive disease may be terminated 48 weeks after seroconversion to anti-HBe, but this cannot be predicted at treatment initiation. Patients with cirrhosis and patients who are anti-HBe positive at treatment initiation, who are started treatment with nucleoside analogs, are expected to receive lifelong treatment, unless HBsAg seroconversion is achieved. Most used nucleoside analogs in Denmark are tenofovir and entecavir. Only with interferon the duration can be determined at treatment start (48 weeks). HBV genotype A and B are more sensitive to interferon than genotype $C$ and $D$, whereas there is no difference in response to nucleoside treatment between genotypes.

\section{Prophylactic Treatment Prior to Immunosuppression}

HBsAg positive patients are recommended to start treatment for hepatitis B prior to immune suppression therapy. Patients who are anti-HBc positive, but negative for HBsAg and anti-HBs ("core only") are monitored by frequent HBV-DNA measurement (initially every month). Patients who become HBV-DNA positive should initiate HBV treatment.

Patients who are anti-HBc and anti-HBs positive may be followed by loss of anti- HBs/appearance of HBsAg.

\section{Treatment for Hepatitis C}

The purpose of treatment for hepatitis $C$ is to prevent cirrhosis and $\mathrm{HCC}$ by eradication of the causal HCV. It has been demonstrated that the cumulative chance of antiviral treatment initiation against chronic hepatitis $\mathrm{C}$, on a nationwide scale in Denmark, was 33\% during 2002-2007 (37). Predictors of antiviral treatment initiation were factors known to predict a better response to treatment (e.g. ALT 2-3>ULN and HCV genotypes 2 and 3) and factors known to increase progression of liver disease (HIV co-infection) (37). Treatment has gradually improved over the last 15 years, first by addition of ribavirin to interferon-alpha treatment, and later by fusion of polyethylene glycol (PEG) to interferon-alpha-2a and interferon-alpha-2b. Peg-interferon-alpha-2a is used in a fixed dose of $180 \mu \mathrm{g} /$ week and peg-interferon-alpha- $2 \mathrm{~b}$ is used weight-based at a dose of $1.5 \mu \mathrm{g} / \mathrm{kg} /$ week. Ribavirin is used on a weight-based dose for HCV genotypes 1/4 and 800 mg daily for genotypes 2/3.

In autumn 2011, the first direct-acting antivirals (DAAs) for treatment of chronic hepatitis $\mathrm{C}$ were introduced in Denmark with the marketing of the NS3 protease-inhibitors telaprevir (Incivo®) and boceprevir (Victrelis ${ }^{\circledR}$ ) as add-on therapy for treatment of HCV genotype 1 infection. Currently sofosbuvir (nucleotide analog) and simeprevir (NS3 protease-inhibitor) are also available.

Treatment for chronic hepatitis $\mathrm{C}$ are considered if a patient fulfills the following two criteria:

1) Positive HCV-RNA for $>6$ months and 
2) Liver biopsy or Fibroscan compatible with moderate to severe fibrosis.

Patients are treated in accordance with national guidelines (34). Although it has been demonstrated that some patients, who are cured of their chronic hepatitis $\mathrm{C}$, achieve regression of the changes in their liver when assessed by Fibroscan (38), patients with cirrhosis before treatment initiation should be followed lifelong, even if they achieve eradication of $\mathrm{HCV}$.

In October 2009 the Board of the Danish Regions established The Council for the Use of Expensive Hospital Medicine with the purpose to ensure that patients are offered equal access to treatment with expensive hospital medicines with due respect to rational pharmacotherapy and a national consensus for the use of expensive hospital medicines. This way, a potential to achieve more favorable prices for the hospitals buying the medicine is established. Antiviral treatment for HCV infection in Denmark is evaluated by this council every second year.

\section{National Immunization Strategies for Hepatitis A and B}

In Denmark, vaccination against hepatitis $A$ is recommended to all adults and children $>1$ year traveling to countries outside Europe, North America and Oceania, as well as to some Eastern European countries and, e.g. Turkey. Persons diagnosed with chronic hepatitis $\mathrm{C}$ are vaccinated free of charge against hepatitis $\mathrm{A}$ and $\mathrm{B}$. Older persons and persons with compromised immune system (immune depression as well as immunodeficiency), who cannot be expected to seroconvert after vaccination, as well as persons in whom vaccination might be contraindicated, are instead protected with gammaglobulin.

The Danish Health and Medicine Authority has recently published a new guideline on HIV, HBVand HCV (39). Universal childhood vaccination is not a part of the Danish hepatitis $B$ prevention program, as this is targeted at high-prevalence groups. In the new guideline, the risk of infection is weighed against the socioeconomic cost of vaccination. It is underlined that the recommendations should be considered minimum recommendations, which may be extended by employers and by the Danish Working Environment Authority. The range of professionals covered by the vaccination recommendation has been changed. Thus, the new guideline recommends vaccination of persons specifically assessed to be at an increased risk, rather than persons belonging to specific professions. This delimitation should be made locally. The list comprises: employees and students, healthcare professionals and others, who are at significant risk of infection transmission and sharps lesions, e.g. due to needle stick or cutting accidents involving blood contaminated syringes, knives, etc.; employees in residential units in institutions for mentally handicapped persons in which one or more of the residents are infected with hepatitis $\mathrm{B}$, employees in day care institutions and private day care services who care for pre-school children diagnosed with chronic hepatitis B.

In Denmark, it is recommended that all newborns of HBsAg positive mothers are vaccinated against hepatitis B at birth. Since 2005, the implementation of universal screening of pregnant women for HBsAg in Denmark has led to $96 \%$ vaccination coverage among newborns (15).

Furthermore, hepatitis B vaccination is recommended to members of households and sexual partners of chronically HBV- infected persons, 4 drug users, patients infected with HIV or HCV, children with Down's syndrome, children in day care where there is a pre-school child diagnosed with chronic hepatitis B, patients undergoing hemodialysis or organ transplantation, patients with hemophilia and MSM.

With regards to travelers, vaccination against $\mathrm{HBV}$ is recommended for persons with employment in health care services, who work in intermediate or high endemic areas of chronic HBV infection, including Greenland. Immunization against HBV is also recommended for travelers, both children and adults, who plan to stay for long periods in areas with intermediate or high endemicity of chronic HBV infection and will have close physical contact with the local population, including children of immigrants to be visiting family in their home country.

Both hepatitis B and hepatitis A vaccines are free of cost for IV drug users, persons infected with $\mathrm{HCV}$, and members of households under 18 years old of chronically HBV infected persons. Furthermore, HBV vaccine is free of charge for members of households over 18 years old and sexual partners of chronically $\mathrm{HBV}$ infected persons, and children in day cares where there is a child with chronic HBV infection.

\section{Conflict of interest: None declared.}

\section{References}

1. Epi-News. Hepatitis A 2011. Denmark: Statens Serum Institut, 2012.

2. Nielsen US, Larsen CS, Howitz M, Petersen E. Hepatitis A among Danish travellers 1980-2007. J Infect. 2009; 58(1): 47-52.

3. Skinhøj P, Høybye G, Hentzer B, Faber V, Poulsen H. Chronic hepatitis B infection in male homosexuals. J Clin Pathol. 1979; 32(8): 783-5.

4. Mazick $A$, Howitz M, Rex S, Jensen IP, Weis $N$, Katzenstein $T L$, et al. Hepatitis A outbreak among MSM linked to casual sex and gay saunas in Copenhagen, Denmark. Euro Surveill. 2005; 10(5): 111-4.

5. Hedberg JC, Gaub J. (Hepatitis epidemic among drug addicts in Esbjerg from July 1993 to May 1994). Ugeskr Laeger. 1995; 157(41): 5701-3.

6. Scheutz F, Skinhøj P, Mark I. Viral hepatitis among parenteral drug addicts attending a Danish addiction clinic. Scand J Infect Dis. 1983; 15(2): 139-43.

7. Epi-News. Hepatitis A 2009. Statens Serum Institut, 2010.

8. MacDonald E, Steens A, Stene-Johansen K, Gillesberg Lassen $S$, Midgley $S$, Lawrence $J$, et al. Increase in hepatitis $A$ in tourists from Denmark, England, Germany, the Netherlands, Norway and Sweden returning from Egypt, November 2012 to March 2013. Euro Surveill. 2013; 18(17): 20468.

9. Gillesberg Lassen S, Soborg B, Midgley SE, Steens A, Vold $L$, Stene-Johansen $K$, et al. Ongoing multi-strain food-borne hepatitis A outbreak with frozen berries as suspected vehicle: four Nordic countries affected, October 2012 to April 2013. Euro Surveill. 2013; 18(17): 20467.

10. Hansen N, Cowan S, Christensen PB, Weis N; DANHEPstyregruppen. (Reporting chronic hepatitis $B$ and $C$ in Denmark). Ugeskr Laeger. 2008; 170(18): 1567-70.

11. Christensen $P B$, Krarup HB, Niesters HG, Norder H, Schaffalitzky de Muckadell OB, Jeune B, et al. Outbreak of Hepatitis B among injecting drug users in Denmark. J Clin Virol. 200; 22(1): 133-41. 
12. Epi-News. http://www.ssi.dk/Aktuelt/Nyhedsbreve/EPI-NYT/2012/ / media/Indhold/DK\% 20-\%20dansk/Aktuelt/Nyhedsbreve/EPINYT/2012/PDF/EPI-NYT\%20-\% 202012\% 20-\% 20Uge\% 2051\%20 -\%20bagside.ash $\times 2012$.

13. Epi-News. Acute and chronic hepatitis B 2010. Statens Serum Institut, 2011.

14. The National Board of Health. Vejledning om forebyggelse mod viral hepatitis, juni 2002: http://www.sst.dk/publ/Publ2002/ hepatitis/html/index.htm. 2002.

15. Harder KM, Cowan S, Eriksen MB, Krarup HB, Christensen PB. Universal screening for hepatitis $B$ among pregnant women led to $96 \%$ vaccination coverage among newborns of $\mathrm{HBsAg}$ positive mothers in Denmark. Vaccine. 2011; 29(50): 9303-7.

16. Epi-News. Hepatitis B, HIV \& syphilis screening of pregnant women, 20122013; 22. Available from: http://www.ssi.dk/ English/News/EPI-NEWS/2013/No\%2022\%20-\%202013.aspx.

17. Krarup $H$, Andersen $S$, Madsen $P H$, Christensen $P B$, Laursen $A L$, Bentzen-Petersen $\mathrm{A}$, et al. $\mathrm{HBeAg}$ and not genotypes predicts viral load in patients with hepatitis B in Denmark: a nationwide cohort study. Scand J Gastroenterol. 2011; 46(12): 1484-91.

18. Epi-News. ACUTE AND CHRONIC HEPATITIS C 20112012; 9.

19. Westh $H$, Worm AM, Jensen BL, Kroon S, Kvinesdal B, Nielsen $\mathrm{CM}$, et al. Hepatitis $\mathrm{C}$ virus antibodies in homosexual men and intravenous drug users in Denmark. Infection. 1993; 21 (2): 115-7.

20. Christensen PB, Groenbaek K, Krarup HB. Transfusion-acquired hepatitis C: the Danish lookback experience. The Danish HCV (hepatitis C virus) Lookback Group. Transfusion. 1999; 39(2): 188-93.

21. Fuglsang T, Fouchard JR, Ege PP. (Prevalence of HIV and hepatitis $\mathrm{B}$ and $\mathrm{C}$ among drug addicts in the city of Copenhagen). Ugeskr Laeger. 2000; 162(27): 3860-4.

22. Mössner BK, Skamling M, Jørgensen TR, Georgsen J, Pedersen C, Christensen PB. Decline in hepatitis B infection observed after 11 years of regional vaccination among Danish drug users. J Med Virol. 2010; 82(10): 1635-9.

23. Krarup HB, Møller JM, Christensen PB, Fuglsang T, Ingerslev $\mathrm{J}$, Arnfred T, et al. Haemophilic patients with hepatitis $\mathrm{C}$ have higher viral load compared to other well-defined patient groups. $J$ Viral Hepat. 2000; 7(6): 435-9.

24. Christensen PB, Hay G, Jepsen P, Omland LH, Just SA, Krarup $H B$, et al. Hepatitis $C$ prevalence in Denmark -an estimate based on multiple national registers. BMC Infect Dis. 2012;12:178.

25. Yaphe S, Bozinoff N, Kyle R, Shivkumar S, Pai NP, Klein M. Incidence of acute hepatitis $\mathrm{C}$ virus infection among men who have sex with men with and without HIV infection: a systematic review. Sex Transm Infect. 2012; 88(7): 558-64.

26. Barfod TS, Omland LH, Katzenstein TL. Incidence and characteristics of sexually transmitted acute hepatitis $\mathrm{C}$ virus infection among HIV-positive men who have sex with men in Copenhagen, Denmark during four years (2006-2009): a retrospective cohort study. Scand J Infect Dis. 2011; 43(2): 145-8.
27. Corbet S, Bukh J, Heinsen A, Fomsgaard A. Hepatitis C virus subtyping by a core-envelope 1-based reverse transcriptase PCR assay with sequencing and its use in determining subtype distribution among Danish patients. J Clin Microbiol. 2003; 41(3): 1091-100.

28. Eriksen MB, Jørgensen LB, Krarup $H$, Laursen $A L$, Christensen PB, Møller A, et al. Molecular and epidemiological profiles of hepatitis C virus genotype 4 in Denmark. J Med Virol. 2010 ; 82(11): 1869-77.

29. Omland LH, Osler M, Jepsen $P$, Krarup $H$, Weis $N$, Christensen $\mathrm{PB}$, et al. Socioeconomic status in HCV infected patients - risk and prognosis. Clin Epidemiol. 2013; 5: 163-72.

30. Omland LH, Krarup $H$, Jepsen P, Georgsen J, Harritshøj LH, Riisom K, et al. Mortality in patients with chronic and cleared hepatitis $\mathrm{C}$ viral infection: a nationwide cohort study. J Hepatol. 2010; 53(1): 36-42.

31. Epi-News. Hepatitis E. Danmark: Statens Serum Institut, 2008 1 October 2008. Report No.

32. Scobie L, Dalton HR. Hepatitis E: source and route of infection, clinical manifestations and new developments. J Viral Hepat. 2013; 20(1): 1-11.

33. Christensen PB, Engle RE, Hjort C, Homburg KM, Vach W, Georgsen J, et al. Time trend of the prevalence of hepatitis E antibodies among farmers and blood donors: a potential zoonosis in Denmark. Clin Infect Dis. 2008; 47(8): 1026-31.

34. Christensen PB, Clausen MR, Krarup $H$, Laursen AL, Schlichting $P$, Weis $N$, et al. Treatment for hepatitis B virus (HBV) and hepatitis $C$ virus (HCV) infection - Danish national guidelines 2011. Dan Med J. 2012; 59(6): C4465.

35. Prati D, Taioli E, Zanella A, Della Torre E, Butelli S, Del Vecchio $E$, et al. Updated definitions of healthy ranges for serum alanine aminotransferase levels. Ann Intern Med. 2002; 137(1): 1-10.

36. Kim HC, Nam CM, Jee SH, Han KH, Oh DK, Suh I. Normal serum aminotransferase concentration and risk of mortality from liver diseases: prospective cohort study. BMJ. 2004 ;328 (7446): 983

37. Hansen N, Obel N, Christensen PB, Krarup $H$, Laursen $A L$, Clausen MR, et al. Predictors of antiviral treatment initiation in hepatitis $C$ virus-infected patients: a Danish cohort study. J Viral Hepat. 2009; 16(9): 659-65.

38. Andersen ES, Moessner BK, Christensen PB, Kjær M, Krarup H, Lillevang $S$, et al. Lower liver stiffness in patients with sustained virological response 4 years after treatment for chronic hepatitis C. Eur J Gastroenterol Hepatol. 2011; 23(1): 41-4.

39. The Danish Health and Medicine Authority. VEJLEDNING OM HIV (HUMAN IMMUNDEFEKT VIRUS) OG HEPATITIS B OG C VIRUS. 2013. 